\title{
Simulation of Photovoltaic Modules using Matlab/Simulink
}

\author{
M Fadlan, W A W Benjamin, H J Lee, P J Ker
}

\begin{abstract}
This paper performs a review on the simulation modules for photovoltaic cells and their recent application. Mathematical modulation is used to simulate the photovoltaic cell and to perform both series and parallel connections. Simulation analysis of photovoltaic modules is done under different weather conditions by varying the irradiance and temperature. The simulation model calculates the output power efficiency of photovoltaic cells. For future application purpose, this research output can be used to predict the desired output power and also to suggest on suitable photovoltaic cells connection for different weather conditions in Malaysia.
\end{abstract}

Keywords: Photovoltaic Cells, Prediction, Simulation, Weather

\section{I.INTRODUCTION}

Today, Malaysia is driving the focus towards renewable energy. Currently, the country is only utilizing $2 \%$ of renewable energy. The Energy, Science, Technology, Environment and Climate Change Ministry (MESTECC) have revised the target to achieve $20 \%$ of renewable energy by 2030 . Hence, the challenge is to look in depth for the possible improvement and advancement in photovoltaic (PV) technology in Malaysia [1]. Research and studies focus on the development of a large scale PV installation towards a clean city [2]. Recent studies focus on the thermal performance of photovoltaic system for the composite climate in Malaysia, the performance of different types of photovoltaic arrays such as Poly-Crystalline; MonoCrystalline and Thin-Film modules were evaluated [3]. Results show that the performance is affected by the solar irradiance and weather condition as well as surrounding environment. In addition, grid-connected PV in Malaysia under tropical climate conditions were also evaluated, it is therefore important to perform the assessment of PV systems for different weather conditions [4].

Prior to PV cells installation, it is important to have a modeling tool that can precisely model the PV cells performance. This is to ensure the efficiency of PV cells vary based on installation location as well as the arrangement structure [5]. It is important to evaluate the performance parameter of large-scale PV cells such as short-

Revised Manuscript Received on November 19, 2019.

M Fadlan, Institute of Power Engineering, College of Engineering, Universiti Tenaga Nasional, Jalan IKRAM-UNITEN, 43000 Kajang, Selangor, Malaysia.

W A W Benjamin, Institute of Power Engineering, College of Engineering, Universiti Tenaga Nasional, Jalan IKRAM-UNITEN, 43000 Kajang, Selangor, Malaysia.

H J Lee, Institute of Power Engineering, College of Engineering, Universiti Tenaga Nasional, Jalan IKRAM-UNITEN, 43000 Kajang, Selangor, Malaysia.

P J Ker, Institute of Power Engineering, College of Engineering, Universiti Tenaga Nasional, Jalan IKRAM-UNITEN, 43000 Kajang, Selangor, Malaysia. circuit current, $\mathrm{I}_{\mathrm{SC}}$ and open circuit voltage, $\mathrm{V}_{\mathrm{OC}}$. This will therefore optimize the cell performance to achieve a high efficiency performance PV cells. Recent study developed a mathematical model to simulate isolation and non-isolation PV array for different weather conditions [6]. Also, Chaibi et al. has developed a novel mathematical model to extract the unknown parameters of PV cells for different weather conditions [7].

This paper gives a detail overview on the different types of simulation tools used to model PV modules. On top of that, this paper simulates the series and parallel connection of PV cells using Matlab simulation to identify on the change in $\mathrm{I}-\mathrm{V}$ and $\mathrm{P}-\mathrm{V}$ output for variation in irradiance and temperature.

\section{II.SIMULATION TOOLS}

This section discussed the available PV simulation tools which include RET Screen, TRNSYS, HOMER, INSEL, PV F-Chart, NREL Solar Advisor Model (SAM), PVsyst, Solar Pro, PV Design, Pro-G, PV*SOL Expert, and MATLAB. Renewable energy technology screen (RET Screen) is an Excel based renewable energy software tool that is used for its technical and financial visibility of renewable potential, energy efficiency and cogeneration projects. It measures the energy efficiency, power and other performance parameter which is applicable for photovoltaic and other renewable energy [8]. Recent study used RET Screen to analyze the PV system in Pakistan area [9]. RET Screen is also implemented to evaluate PV cells on apartment [10].

Transient Systems Simulation (TRNSYS) applies numerical models to generate and alter the majority of nongeometrical data [11]. TRNSYS has recently being used to simulate the energy consumption and costing evaluation for power plant PV evaluation in Spain [12]. Hybrid Optimization Model for Electric Renewable (HOMER) is another simulation tool which is suitable for both on and off-grid PV systems. HOMER's calculation is used for the variety in innovation expenses and asset accessibility, using renewable energy as the input parameter [13]. Deshmukh et al. used HOMER for PV simulation in India [14]. Singh et al. has also performed simulation on PV cells and other renewable energy using HOMER [15].

Integrated Simulation Environment Language (INSEL) is the simulation block for programming applications. INSEL offers interface in programming such as Fortran and $\mathrm{C} / \mathrm{C}++$. One main advantage of INSEL is that it can run with MATLAB ${ }^{\circledR}$ which offers collection of model segments for an assortment of reproduction applications [16]. In addition, Photovoltaic F-Chart (PV F-Chart) is an extensive photovoltaic framework investigation and configuration program. PV F-Chart is able to include more than 300 locations at the user end level, 
where the battery system andstand-alone PV system can be utilized [17]. PV F-Chart can study the change in energy production and performance based on load varieties [18]. Brugahan et al. has used PV F-Chart to perform a comparison between solar cell performance and nuclear power [19].

Another type of available simulation software is the National Renewable Energy Laboratory Solar Advisor Model (NREL SAM). It is an outstanding simulation model which is commonly used in the renewable energy business to execute different types of renewable power sources together with the financial investigation [20]. The improvement of the solar advisor model was also reported recently [21]. Photo Voltaic systems (PVsyst) are extremely accommodating educative applications which perform rapid characterization of PV framework. Variations reproduction can be done to achieve advancement and parameter examinations with respect of irradiance and cell temperatures. Most often, PVsyst is used in project financing and energy yield prediction [22]. Kumar et al. [23] and [24] have used PVsyst in investigating the string and arrays of PV cells.

Solar Pro is another type of advanced simulation program for PV framework which investigates the power performance under various environment conditions. Solar Pro is able to simulate the shadow influence from the surrounding building. This gives an optimal setting to the users for PV installation based on the accurate electrical characteristics which takes into consideration both the environment condition and climate parameters [25]. Thula et al. has recently perform simulation for $100 \mathrm{kWp}$ solar power using SolarPro [26]. Photovoltaic Design Program - Grid connected Systems (PV-Designer) is software to simulate the photovoltaic energy based on climate change [27]. PVDesign Pro is best use to provide an in-depth of financial analysis and operating system on power output and optimum load consumption for PV module.

Another type of simulation tool is the PV*SOL Expert which is a 3D software for PV design, this software has a few outstanding key performances such as wiring design, analysis on partial shading as well as overall full component selection [28]. Khatib has also reviewed on the functionality of $\mathrm{PV} * \mathrm{SOL}$ Expert in solving PV for partial shading condition [18]. However, further research work is needed to improve the accuracy of simulation tool.

Lastly, MATLAB simulation is commonly used for PV simulation [29]. This is because MATLAB's Simulink block library Graphic User Interface (GUI) is very user friendly to design PV modules and to determine the P-V and I-V output. This paper models the photovoltaic (PV) module using the MATLAB/Simulink software. The P-V and I-V output characteristics are studied under different temperature and solar irradiation conditions [30]. For future application purpose, the accurate simulation tool can be used to design suitable types of PV installation for different weather conditions.

\section{III.SIMULATION METHODOLOGY}

Solar cells are interconnected to shape a module of certain voltage/current dimension. These modules can be interconnected to design the voltage and current level. PV array is a gathering of interconnected PV modules by having the solar cells in both series and parallel connection. The proportionate circuit of rearranged PV cell involves a present source, two diodes, series and parallel of resistor over the load as in Fig. 1 [15].

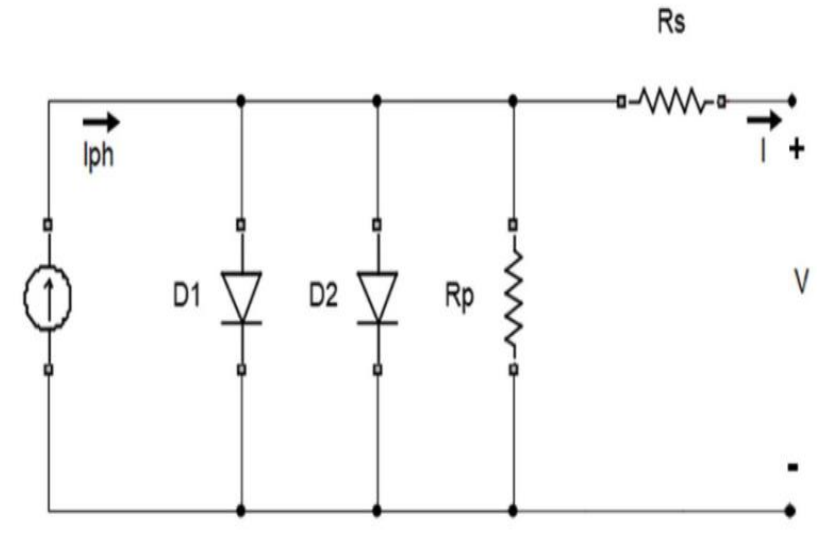

Fig. 1 Equivalent circuit of PV cell

Simulation model of the subsystem for one PV module is created by utilizing conditions in MATLAB/Simulink. The connection between yield present and terminal voltage is given as pursues:

$$
I=I_{p h}-I_{O}\left(e^{q\left(\frac{V+1 \cdot R_{s}}{n K T}\right)}-1\right)-\left(\frac{V+I \cdot R_{S}}{R_{p}}\right)
$$

For series connected PV modules, a PV string comprising of three PV modules are associated in series have been simulated by building up the simulation display as shown in Fig. 2. For parallel connected PV modules, a PV array comprises of six number of PV modules associated in series and parallel have been simulated by making the simulation model as in Fig. 3. All the simulation model is produced by utilizing standard appraisals as given in Table 1.

Table. 1 Parameters on PV modules

\begin{tabular}{|c|c|c|}
\hline No. & Parameters & Value \\
\hline 1. & Temperature (Te) & $25^{\circ} \mathrm{C}$ \\
\hline 2. & Irradiance (Sun) & 1000 \\
\hline 3. & Series Resistance (Rs) & $0.008 \Omega$ \\
\hline 4. & Shunt Resistance (Rsh) & $1000 \Omega$ \\
\hline
\end{tabular}




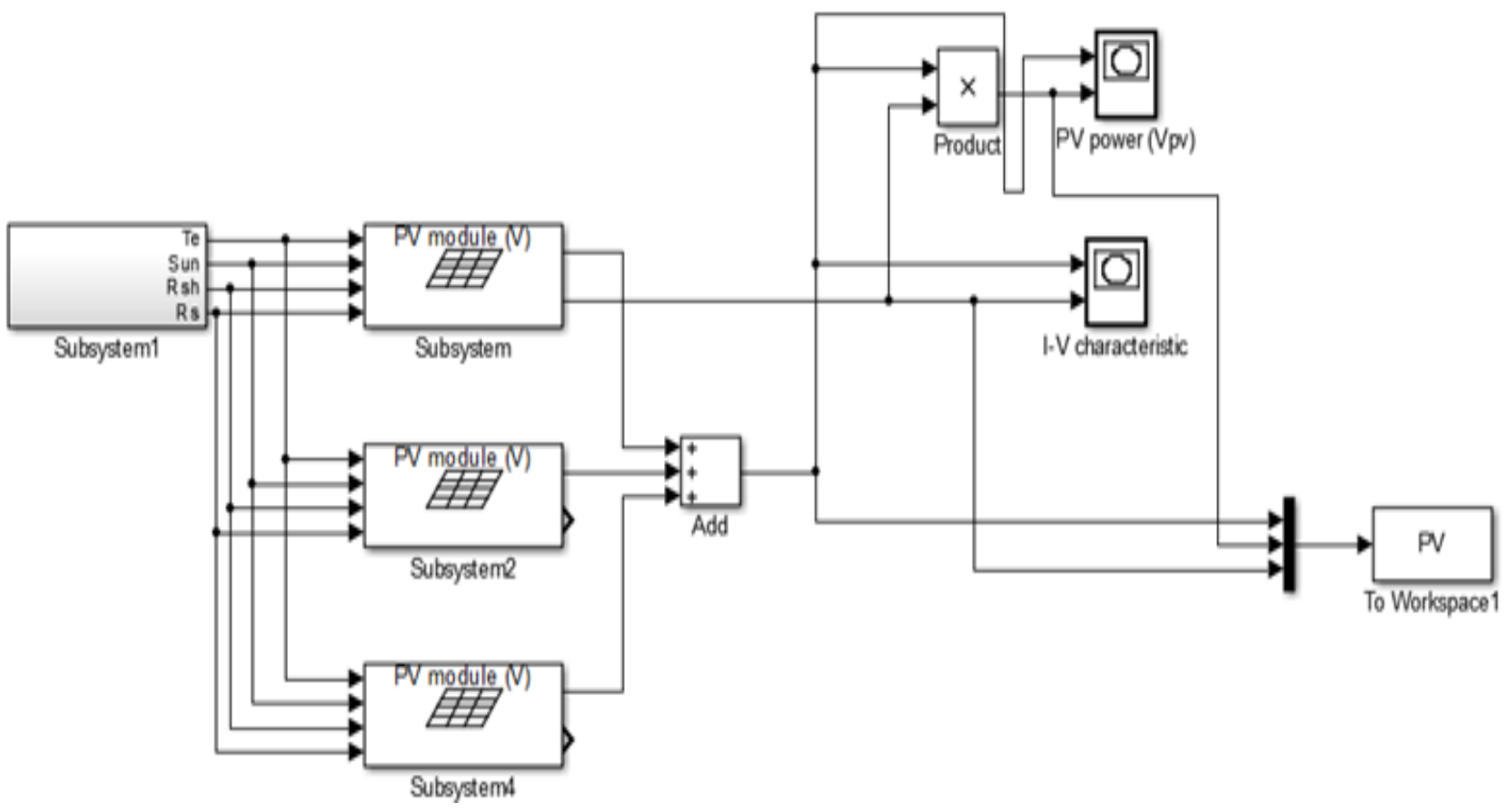

Fig. 2 Series connected PV modules

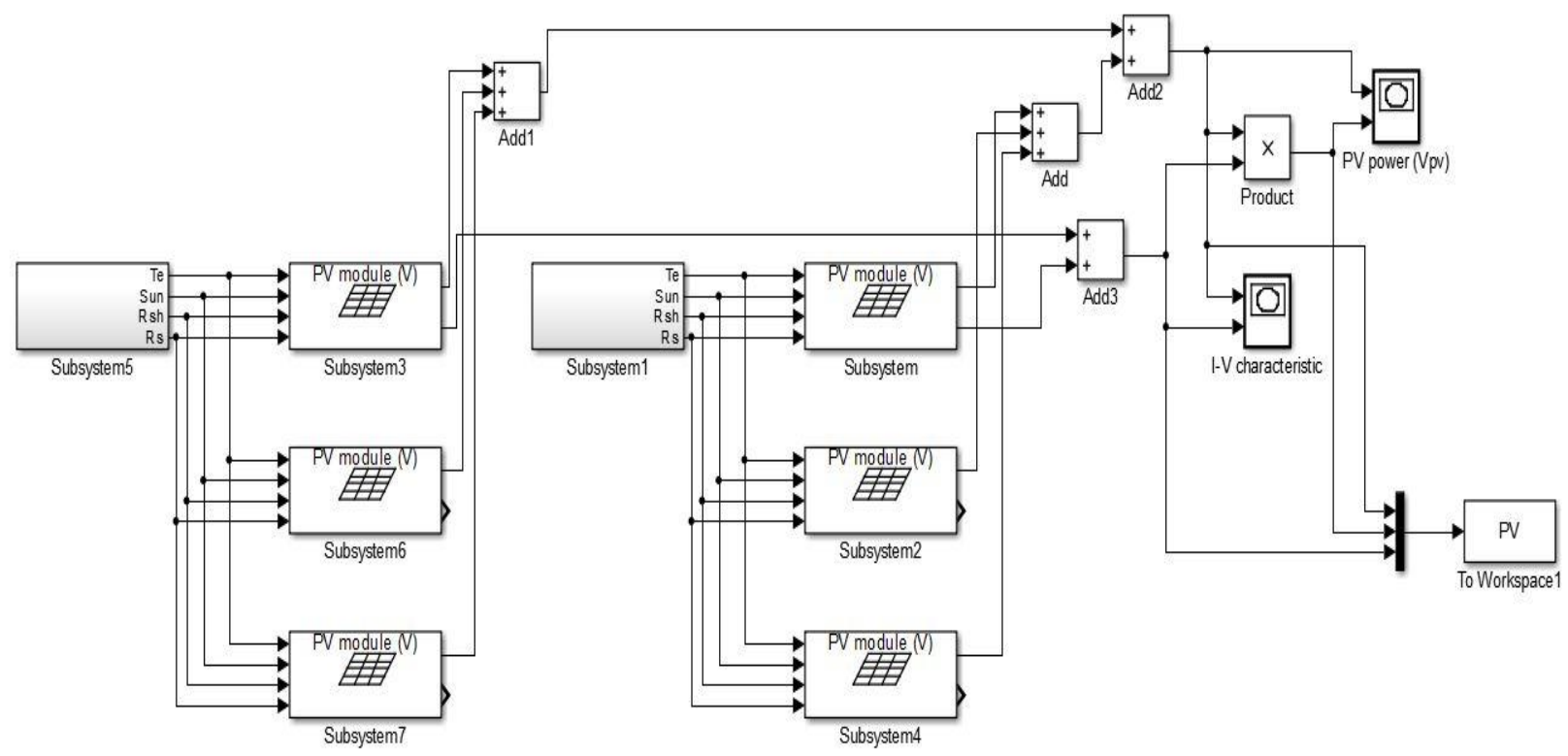

Fig. 3 Series and parallel connected PV modules

\section{IV.RESULTS AND DISCUSSIONS}

Under non-uniform isolation level, the Current-Voltage (I-V) and Power-Voltage (P-V) characteristic of PV modules are presented in Fig. 4 and Fig. 5 for series connection while Fig. 8 and Fig. 9 are for parallel connection. The PV modules are developed with constant temperature of $25^{\circ} \mathrm{C}$ and different level of irradiance at 200, $400,600,800,1000 \mathrm{~W} / \mathrm{m}^{2}$. The Current-Voltage (I-V) and Power-Voltage (P-V) characteristic of PV modules are presented in Fig. 6 and Fig. 7 for series connection while Fig. 10 and Fig. 11 are for parallel connection. The PV modules are developed with constant irradiance of 1000 $W / \mathrm{m}^{2}$ and different level of operating temperatures at 20, 25, 30, 35, $40{ }^{\circ}$ C. Fig. 4, Fig. 5, Fig. 8 and Fig. 9 show the characteristic with the constant operating temperature of 25 ${ }^{\circ} \mathrm{C}$ and different levels of irradiance. It is to be noticed that however the results were obtained with different level of irradiance, but each time every module gets a similar curve of insolation. The output power that obtained in parallel connection is greater than the series connection. In each of the case introduced, Power-Voltage $(\mathrm{P}-\mathrm{V})$ characteristic shows only a single maximum power point (MPP).

Fig. 6, Fig. 7, Fig. 10 and Fig. 11 show the characteristic with constant irradiance values and different level of operating temperatures. For both series and parallel connections, the results show that the higher temperature will produce more output power for the PV modules. The impact of fractional shading in photovoltaic strings, through various parameters and arrangements has been examined

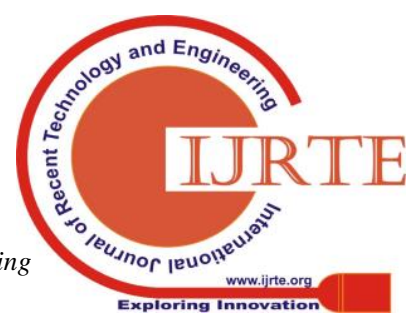


tentatively by utilizing MATLAB/Simulink programming. The simulation model is dependent on mathematical conditions from a circuit of photovoltaic cell. The simulation model is sensible to study the solar cells performance working under different environmental conditions. An outline table of the recreation results for different conditions is listed in Table 2. It is therefore crucial to study the cell performance with respect for weather conditions, suitable PV cell arrangement can then be later introduced for different weather conditions. In such case, optimum power can be harvested based on different weather conditions.

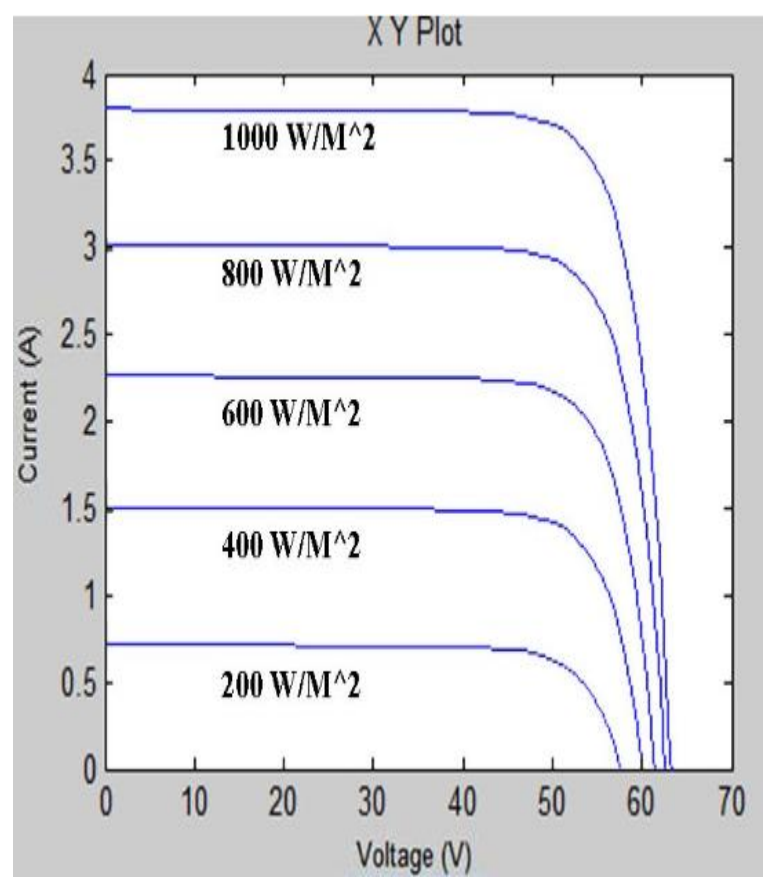

Fig. 4 I-V for series connection with various irradiance

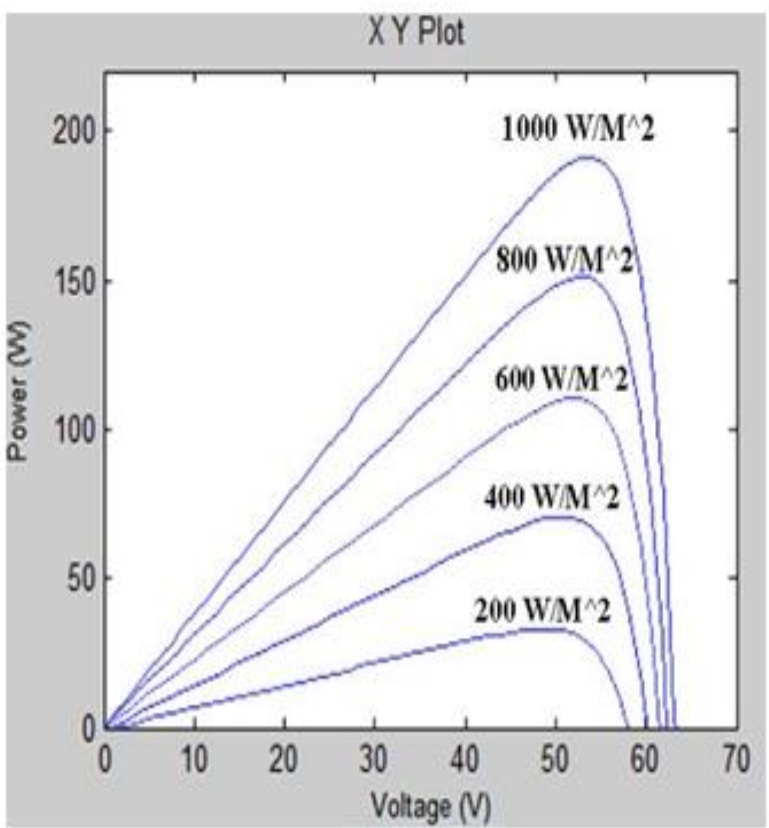

Fig. 5: P-V for series connection with various irradiance

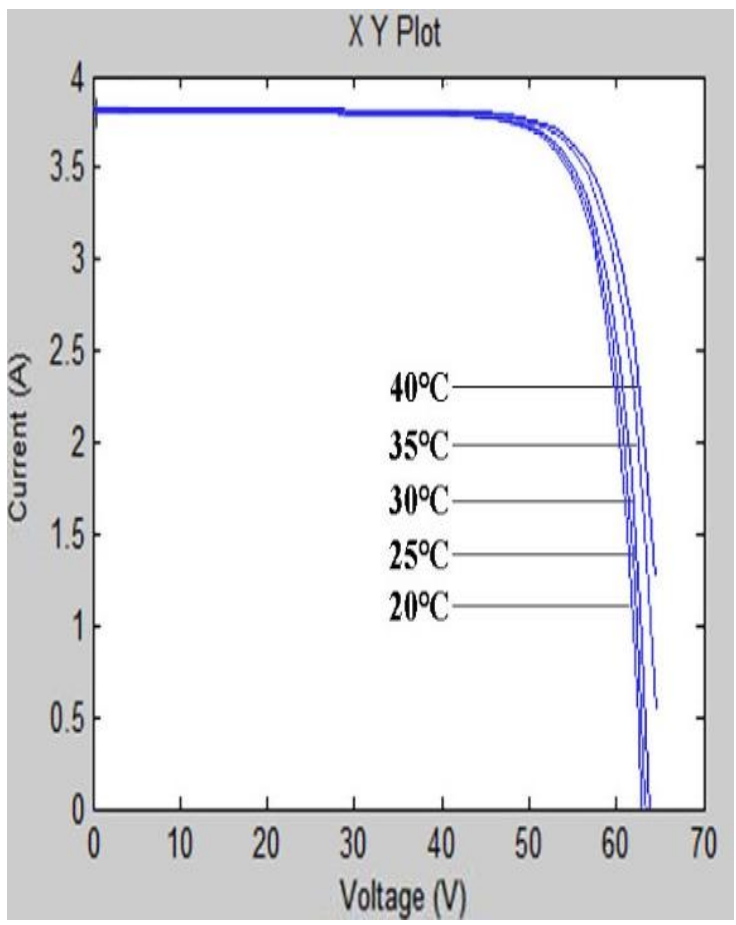

Fig. 6 I-V for series connection with various temperature

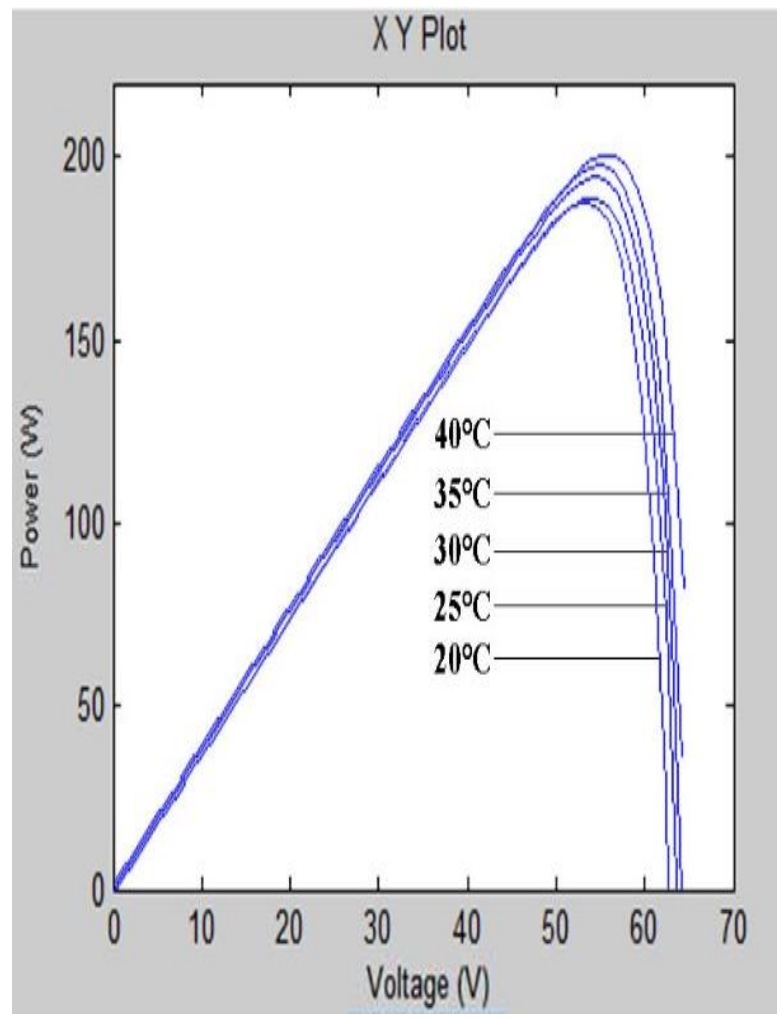

Fig. 7 P-V for series connection with various temperature 
Table. 2 Simulation Results of Series and Parallel Connection

\begin{tabular}{|c|c|c|c|c|c|c|c|c|}
\hline & & & & Series & & & Para & \\
\hline & & & $\begin{array}{c}\text { Current } \\
\text { (A) }\end{array}$ & $\begin{array}{c}\text { Voltage } \\
\text { (V) }\end{array}$ & $\begin{array}{c}\text { Power } \\
\text { (W) }\end{array}$ & $\begin{array}{l}\text { Current } \\
\text { (A) }\end{array}$ & $\begin{array}{c}\text { Voltage } \\
\text { (V) }\end{array}$ & $\begin{array}{c}\text { Power } \\
\text { (W) }\end{array}$ \\
\hline Under U & form Insolation Lev & & 3.80 & 64 & 185 & 7.50 & 128 & 760 \\
\hline Under Non- & & 20 & 3.80 & 62 & 180 & 7.50 & 125 & 740 \\
\hline Insolation Level & Temperature $\left({ }^{\circ} \mathrm{C}\right)$ & 25 & 3.80 & 64 & 185 & 7.50 & 128 & 760 \\
\hline (Partially Shaded & & 30 & 3.80 & 66 & 190 & 7.50 & 135 & 780 \\
\hline & & 35 & 3.80 & 68 & 195 & 7.50 & 140 & 785 \\
\hline & & 40 & 3.85 & 70 & 205 & 7.70 & 145 & 800 \\
\hline & & 1000 & 3.80 & 64 & 185 & 7.50 & 128 & 760 \\
\hline & $\begin{array}{l}\text { Irradiance } \\
\left(W / m^{2}\right)\end{array}$ & 800 & 3.05 & 63 & 150 & 6.10 & 125 & 600 \\
\hline & & 600 & 2.30 & 62 & 120 & 4.30 & 122 & 420 \\
\hline & & 400 & 1.50 & 61 & 70 & 3.00 & 120 & 300 \\
\hline & & 200 & 0.80 & 58 & 30 & 1.20 & 115 & 100 \\
\hline
\end{tabular}

\section{V.CONCLUSIONS}

The result of partial shading conditions in photovoltaic strings using various configurations and values have been simulated using MATLAB/Simulink software. The simulation model is produced based on mathematical equations derived from a circuit of photovoltaic cell. The equations then are carefully converted into block parameters inside MATLAB/Simulink simulation software. The electrical performance of series and parallel connected PV modules has been explored to discover a design which is more efficient during various weather conditions. Furthermore, the simulation model is also convenient to design for the most ideal configuration of the PV modules to extract the maximum power. For future usage, the simulation tool can be used to propose on suitable combination of PV cell structure for different location in Malaysia with different weather conditions. Such contribution would be significant to ensure an optimum power harvesting from solar energy.

\section{ACKNOWLEDGMENTS}

The authors acknowledge UNITEN UNIIG J510050780 and BOLD 2025 10463494/B/2019072 for the support.

\section{REFERENCES}

1. M. S. Hossain, A. K. Pandey, J. Selvaraj, N. Abd Rahim, A. Rivai, and V. V. Tyagi, "Thermal performance analysis of parallel serpentine flow based photovoltaic/thermal (PV/T) system under composite climate of Malaysia," Appl. Therm. Eng., no. November 2018, pp. 1-11, 2019

2. N. A. Rahim, H. S. Che, M. Hasanuzzaman, and A. Habib, "Toward Cleaner Cities: Renewable Energy Initiatives in Malaysia," Devising a Clean Energy Strateg. Asian Cities, pp. 165-185, 2018.

3. L. M. Halabi and S. Mekhilef, "Performance Analysis of MultiPhotovoltaic (PV)-Grid Tied Plant in Malaysia," IOP Conf. Ser. Earth Environ. Sci., vol. 164, no. 1, 2018.

4. A. M. Humada, A. M. Aaref, H. M. Hamada, M. H. Sulaiman, N.
Amin, and S. Mekhilef, "Modeling and characterization of a gridconnected photovoltaic system under tropical climate conditions," Renew. Sustain. Energy Rev., vol. 82, no. August 2017, pp. 2094$2105,2018$.

5. Z. Abdin, C. J. Webb, and E. M. A. Gray, "Simulation of large photovoltaic arrays," Sol. Energy, vol. 161, no. January, pp. 163-179, 2018.

6. S. K. Jha, "Characteristics Under Partial Shading," no. 1, pp. 642-646, 2017.

7. Y. Chaibi, M. Salhi, A. El-jouni, and A. Essadki, "A new method to extract the equivalent circuit parameters of a photovoltaic panel," Sol. Energy, vol. 163, no. October 2017, pp. 376-386, 2018.

8. D. Thevenard, G. Leng, and S. Martel, "The retscreen model for assessing potential PV projects," Conf. Rec. IEEE Photovolt. Spec. Conf., vol. 2000-Janua, pp. 1626-1629, 2000.

9. Y. A. Bhutto, M. A. Mahar, A. S. Larik, S. H. Bhellar, and A. Khuwahar, "Analysis of Photovoltaic System at Various Sites of Pakistan Using," vol. 2, no. 1, pp. 7-13, 2018.

10. A. J. Aristizábal Cardona, C. A. Páez Chica, D. H. Ospina Barragán, A. J. Aristizábal Cardona, C. A. Páez Chica, and D. H. Ospina Barragán, "Integrated Photovoltaic System Sizing and Economic Evaluation Using RETScreen ${ }^{\mathrm{TM}}$ for a Building of 40 Apartments," Build. Photovolt. Syst., pp. 35-46, 2018.

11. W. A. Beckman et al., "TRNSYS The most complete solar energy system modeling and simulation software," Renew. Energy, vol. 5, no. 1-4, pp. 486-488, 1994.

12. M. Villa-Arrieta and A. Sumper, "A model for an economic evaluation of energy systems using TRNSYS," Appl. Energy, vol. 215, no. December 2017, pp. 765-777, 2018.

13. T. Givler and P. Lilienthal, "Using HOMER Software, NREL's Micropower Optimization Model, to Explore the Role of Gen-sets in Small Solar Power Systems; Case Study: Sri Lanka," no. May, 2005.

14. M. K. Deshmukh and A. B. Singh, "Modeling of energy performance of stand-alone SPV system using HOMER pro," Energy Procedia, vol. 156, no. September 2018, pp. 90-94, 2019.

15. H. Bellia, R. Youcef, and M. Fatima, "A detailed modeling of photovoltaic module using MATLAB," NRIAG J. Astron. Geophys., vol. 3 , no. 1, pp. 53-61, 2014.

16. J. Luther and J. Schumacher-Gröhn, "INSEL - A Simulation System for Renewable Electrical Energy Supply Systems," Tenth E.C. Photovolt. Sol. Energy Conf., no. April, pp. 457-460, 2011.

17. H. Fayaz, N. A. Rahim, R. Saidur, and M. Hasanuzzaman, "Technoeconomic Analysis of Evacuated Tube Solar Water Heater using Fchart Method," IOP Conf. Ser. Mater. Sci. Eng., vol. 358, no. 1,

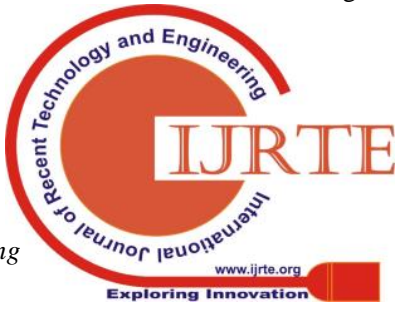


2018.

18. T. Khatib, A. Mohamed, and K. Sopian, "A Software Tool for Optimal Sizing of PV Systems in Malaysia," Model. Simul. Eng., vol. 2012, pp. $1-11,2012$.

19. A. B. Karaveli, U. Soytas, and B. G. Akinoglu, "Comparison of large scale solar PV (photovoltaic) and nuclear power plant investments in an emerging market," Energy, vol. 84, pp. 656-665, 2015.

20. [20] N. Blair et al., "System Advisor Model, SAM 2014.1.14: General Description," no. February, 2014.

21. N. Renewable, "DE-EE00030360 Improvement and Validation of the System Advisor Model National Renewable Energy Laboratory," pp. 1-31, 2018.

22. K. J. Sauer, T. Roessler, and C. W. Hansen, "Modeling the irradiance and temperature dependence of photovoltaic modules in PVsyst," IEEE J. Photovoltaics, vol. 5, no. 1, pp. 152-158, 2015.

23. N. M. Kumar, M. R. Kumar, P. R. Rejoice, and M. Mathew, "Performance analysis of $100 \mathrm{kWp}$ grid connected Si-poly photovoltaic system using PVsyst simulation tool," Energy Procedia, vol. 117, pp. 180-189, 2017.

24. Y. M. Irwan et al., "Stand-Alone Photovoltaic (SAPV) System Assessment using PVSYST Software,” Energy Procedia, vol. 79, pp. 596-603, 2015.

25. M. Lalwani, D. P. Kothari, and M. Singh, "Investigation of Solar Photovoltaic Simulation Softwares," Int. J. Appl. Eng. Res. Dindigul, vol. 1, no. 3, pp. 585-601, 2010.

26. M. Thula, M. N. Kumar, and V. S. Reddy, "Simulation and performance analysis of $100 \mathrm{kWp}$ solar rooftop using Solar Pro software," 2017 Innov. Power Adv. Comput. Technol. i-PACT 2017, vol. 2017-January, pp. 1-5, 2018.

27. D. K. Sharma, V. Verma, and A. P. Sing, "Review and Analysis of Solar Photovoltaic Softwares," [1] H. Z. ̃̃ al., "The Hist. solar," Sol. Energy Mater. Sol. Cells, vol. 93, pp. 1461-1470, 2011. [2] T. First P. Cell, "A Short Hist. Photovolt. ( PV ) Cells," Genes. Energy, pp. 1-12, 2015. [3] N. A. Ahmad A. A. Abdul-Ghani, "Towar, vol. 4, no. 2, pp. 725-731, 2014.

28. J. Freeman, J. Whitmore, N. Blair, and A. P. Dobos, "Validation of multiple tools for flat plate photovoltaic modeling against measured data," 2014 IEEE 40th Photovolt. Spec. Conf. PVSC 2014, pp. 1932 1937, 2014.

29. B. Mohammed Salih, R. A. Mohmeed, and M. Ahmed Ibrahim, "The environment coefficients effect on I-V and P-V characteristics curves of photovoltaic cell using Matlab/Simulink,” Int. J. Eng. Technol., vol. 7, no. 4, pp. 2651-2654, 2018.

30. N. Sarma, K. Gegin, M. Simsir, and N. Tutkun, "Modeling of a Typical Photovoltaic Module using Matlab/Simulink," ISMSIT 2018 - 2nd Int. Symp. Multidiscip. Stud. Innov. Technol. Proc., pp. 5-10, 2018.

31. Manikanthan, S.V., Padmapriya, T., "An efficient cluster head selection and routing in mobile WSN" International Journal of Interactive Mobile Technologies, 2019. 